\title{
Transborder Surface Movements Of Nafta Commodities-Truck vs Rail
}

H. Barry Spraggins (E-mail: spraggin@scs.unr.edu), University of Nevada, Reno John Ozment (E-Mail: jozment@ comp.uark.edu), University of Arkansas

\begin{abstract}
The boom in NAFTA trade has created a corresponding surge in the demand for surface transportation capacity to move the goods. So far, trucks have provided the major capacity to meet the requirements. Intensive lobbying efforts are being made for authority to utilized longer and heavier trucks along certain U.S. highway corridors to move the imports and exports from and to Canada and Mexico. In addition, a serious debate has erupted over allowing Mexican trucks to travel significant distances within the U.S. The surge in surface NAFTA based commodity movement via truck has serious economic, social and infrastructure consequences.
\end{abstract}

The paper examines the surface transborder export-import flows between the U.S. and Canada and the U.S. and Mexico. Delineating these flows by the types of commodities, origins and destinations, and modal movements is an essential ingredient in any attempt to determine if the transportation infrastructure is being and will be utilized in optimum manner. Specifically, the paper finds that the overwhelming percentage of commodity movements is by truck regardless of distance traveled with very little moving by rail. The paper looks at the potential for commodity adaptability and flows to rail movement. Environmental considerations are also integrated into the trade-offs. Cost and service of trucking versus rail are the key ingredients to the conclusions.

\subsection{Introduction}

M

erchandise trade among Canada, the U.S., and Mexico has increased significantly since the implementation of NAFTA. The United States and Canada are each other's largest trading partner. North-south trade with Mexico is also continuing to surge. The value of transborder surface freight movement of commodities crossing the U.S./Canadian and U.S./Mexican borders reached $\$ 575,713,240,000$ in 2000 compared to $\$ 311,602,304,336$ in 1994, an 66\% increase when adjusted for current dollar value (Bureau of Transportation Statistics, 2002).

Among the many factors that affect a country's ability to trade competitively with another country include the capacity and efficiency of its transportation system. Utilizing an efficient and adequate transportation system to receive and market goods helps insure that a region remains competitive and does not lose business to other regions that have superior transportation modal networks that can move products to and from markets faster, cheaper, and more efficiently. The role transportation modes play in today's NAFTA environment is one of the prime concerns of this paper.

\subsection{NAFTA Export-Import Trends}

There is no doubt the NAFTA agreements have contributed to the continuing acceleration in commodity movements among the NAFTA countries. On an inflation adjusted basis, land transportation movements across borders, known as transborder surface movement (TSM) have increased significantly. TSM exports from the U.S. to Canada increased by 44 percent from 1994 to 2000. TSM imports increased by an impressive 81 percent during

Readers with comments or questions are encouraged to contact the authors via email. 
the same period. Mexican trade with the U.S. increased at an even more rapid pace percent wise. TSM exports from the U.S. to Mexico increased 111 percent during the period while imports from Mexico increased an astounding 170 percent. Overall, transborder surface trade with Canada increased 63 percent during the period while transborder surface trade with Mexico jumped 138 percent (Bureau of Transportation Statistics, 2002). These upward trends in value of commodity movements with Canada and Mexico are vividly shown in Figure 1.

\subsection{NAFTA Transportation Concerns}

The phenomenal boom in NAFTA trade has generated added demands on the North American transportation system. So far, trucks have provided the major capacity to meet the burgeoning requirements. Trucking exportimport growth levels have put two intensive trucking lobbying efforts in play. One is for authority to utilize longer and heavier trucks along certain U.S. highway corridors to move the large volume of international goods in North America. The CANAMEX (I-15) and I-5 highway corridor proposals are an example of one approach to meeting the increasing transportation needs for exports and imports. CANAMEX is the most direct north-south corridor for Alberta and the U.S. CANAMEX is an acronym drawn from CANada, AMerica, and MEXico (CANAMEX Trade Corridor, 1997). It encompasses a proposed 2,000-mile, north-south highway trade route extending from the northwest part of Alberta through Montana, Idaho, Utah, and Arizona to points in Nevada and California. Ultimately, when and if U.S. route 93 adjacent to the Hoover Dam is upgraded to an interstate highway, this corridor will extend into Arizona and through to Mexico. The I-5 corridor parallels the west coast and connects California, Oregon, Washington, and British Columbia. CANAMEX and I-5 are two of a number of north-south highway systems designated as high-priority trade corridors under the Canadian National Highway System Designation Act of 1995. Enactment of such legislation has serious economic, social, and infrastructure consequences.

The second far-reaching issue is that of Mexican trucks operating in the United States. The Bush administration has set January 1, 2002 as the target date for launching international trucking with Mexico. The teamsters contend "Unsafe Mexican trucks cross our southern border more than 4 million times a year." The teamsters project that this Mexican truck traffic will increase to more than 7 million crossings after January 1, 2002. The unsafe Mexican truck factor is born out by the Department of Transportation Inspector General's report in 2000 showing a 36\% out-of-service rate for Mexican trucks at border points due to safety defects (Transport Topics, 2001).

\subsection{U. S. Surface Commodity Movements with Canada and Mexico}

Defining the commodity flows and distances of products moving among the three NAFTA partners is a necessity in determining the future ability of each transportation mode to transport NAFTA commodities. Figures 2 and 3 break down the value of the commodity movements since 1994 by the transborder surface modes with Canada and Mexico respectively. It is noteworthy in both cases that rail has shown very little increase in traffic since 1994 while the value of commodities moving by truck has doubled during the same period. Figures 4 and 5 break down the movement into exports and imports between the U.S. and Canada and the U.S. and Mexico. Several observations can be made. Canadian transborder surface export-import commodity flows are primarily moved by truck. However, truck exports to Canada in 2000 slightly exceeded truck imports from Canada. Just the opposite is true for rail. Rail import values from Canada are almost four times the rail export value to Canada. As in the case with Canada, trucking hauls by far the largest proportion of the goods between the U.S. and Mexico. Rail has, in fact, lost percent share since 1994, increasing their total value of export goods moved by a mere $\$ 1,500,000$. Rails have managed to double the amount of import goods from 1994, but this amount still pales in comparison to the increase in truck import movement. As was not the case with Canada import truck traffic, Mexican truck imports exceed export truck traffic to Mexico. 


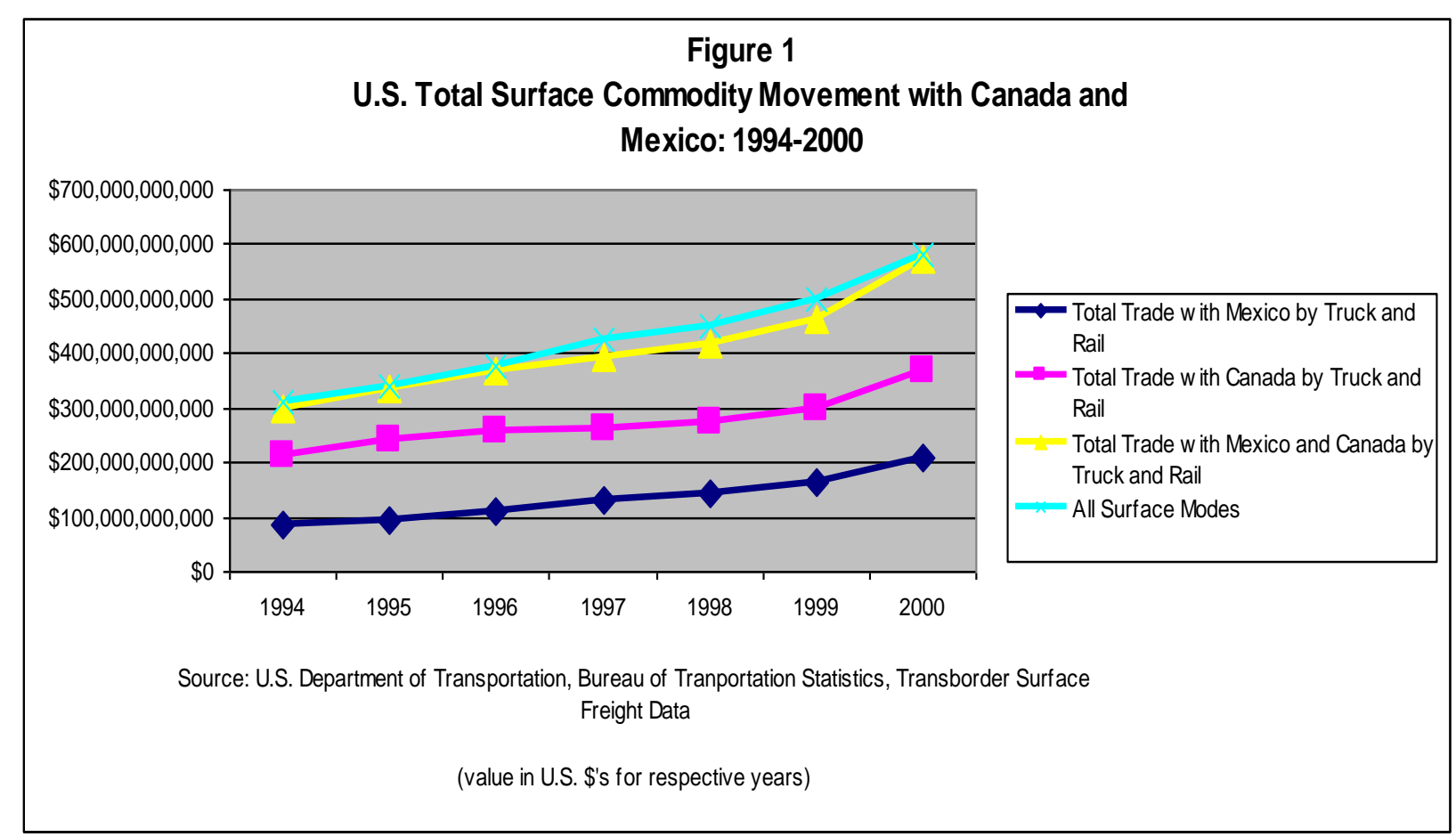

\subsection{Specific Commodity Movements}

Export Commodities From the U.S. to Canada:

Of the top 25 export commodities to Canada from the U.S. ranked by commodity value of commodities moved by all surface modes across border points, truck easily has the largest share of movement for all of the commodities. Out of the 25 , rail moves only five commodities with more than a 10 percent share of the total value of the traffic; the largest being organic chemicals with a $43.31 \%$ share. Vehicles and plastics account for $65 \%$ of the entire rail export traffic to Canada in 2000. The top three commodities in the table: vehicles, nuclear reactors, and electrical equipment account for over $50 \%$ of the total truck traffic.

Import Commodities From Canada to the U.S.:

As previously noted, trucks fare much better than rail in the category of imports from Canada. However, rails do have significant shares in several commodity categories. In seven categories, rail haul more than $40 \%$ of the value of the goods with fertilizers being the largest at $83 \%$. As far as total value goes, vehicles, nuclear reactors, and electrical machinery account for $44 \%$ of the truck total for Canadian imports. Rail movement is even more focused with more than $50 \%$ of the value of import movement by rail being vehicles. 

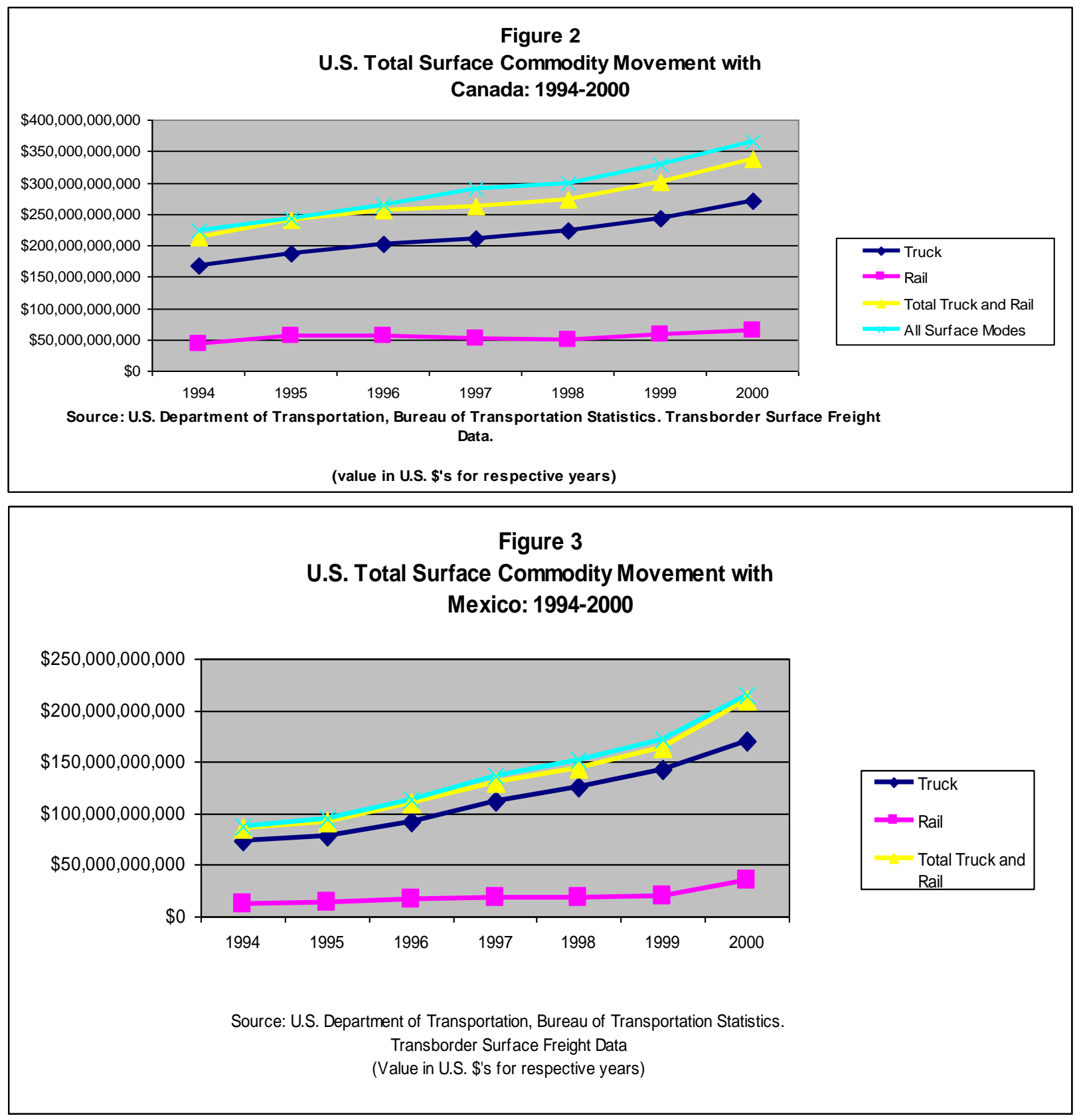

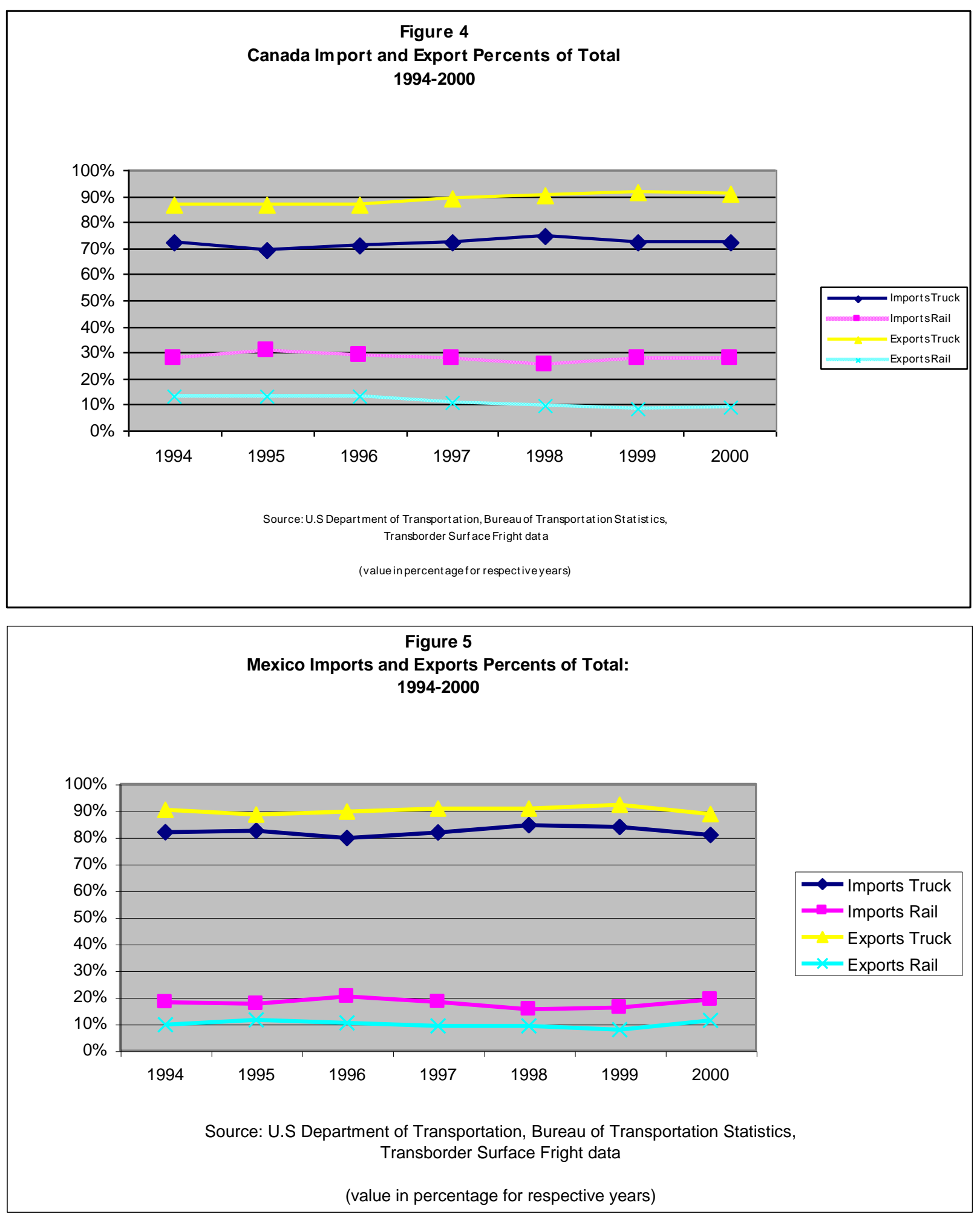
Export Commodities From the U.S. to Mexico:

As was the case with Canada, export commodities to Mexico are overwhelmingly moved by truck. There are eleven export commodity categories out of the top 25 where rail moves more than $10 \%$ of that particular commodity. Tanning extracts and oil seeds are the only two categories where rail has over a $50 \%$ of the total commodity movement. As far as commodity value goes, vehicles are the number one export commodity movement for rails. Vehicles make up 28\% of the total value of goods the rails move from the U.S. to Mexico. Electrical machinery, nuclear reactors, and vehicles account for $50 \%$ of the total export commodity value for trucks.

Import Commodities From Mexico to the U.S.:

Import commodities moving from Mexico to the U.S. are truck dominated. Only six commodities give rail more than a $10 \%$ share of the total value of traffic. Three commodity categories, rail locomotives, vehicles, and beverages, provide rail with more than a majority share of 50 percent of the traffic for that particular commodity. Vehicles provide rails $78 \%$ of its total import commodity value movement. Electrical machinery and nuclear reactors together provide $47 \%$ of the total value for trucking import movement.

\subsection{Export-Import State Commodity Flows}

Exports from States to Provinces:

Ontario appears to be the largest export Canadian target for the U.S. Forty percent of the commodity value moving from Michigan and Ohio are vehicles. Georgia is the only state exporting to Canada that has a significant share moving by rail, $37 \%$. The value of transborder surface freight in 2000 from Michigan, Ohio, and Illinois to Canada constituted about $28 \%$ of the total U.S. exports to Canada.

Illinois was the largest exporter to Canada by rail in 2000, followed by Texas, Ohio, and Michigan. Michigan, Ohio, New York, and Illinois were the big truck movement exporters.

Imports from Provinces to States:

Ontario again is the big trade partner with the largest movements to Michigan in the form of vehicles. In fact $75 \%$ of the rail commodity movement to Michigan and New York is vehicles. There are only two province-state movements where rail had more than a 50\% share of the traffic, Ontario to California and Quebec to Michigan. Over $41 \%$ of the value of imports from Canada by surface freight flows, in value order, to Michigan, New York, and California. Michigan receives the most value in surface freight commodities via rail; more than three times the amount of each of the next two states, New York and California. Michigan is also the favorite destination by truck. It exceeds the second place state, New York, by $40 \%$.

Exports from U.S. States to Mexican States:

Trade from Texas to Chihuahua is the largest single export combination. Electrical machinery and vehicles account for $40 \%$ of the total value of 2000 commodity movement. Rail has a micro-share of this Texas-Chihuahua movement. Movement from California to Baja California is the second largest export combination. Over $50 \%$ of the commodity movement value involves electrical machinery and nuclear reactors. Again, rail has no real movement in this combination. Of the 25 top combinations, rail only has four combinations where its share is around 20 percent or above. Texas is by far the largest single export state to Mexico via rail. Export movements from Texas by rail constitute over $48 \%$ of all surface transborder state exports by rail to Mexico. Texas, California, and Arizona are the three largest export states via surface freight to Mexico. These three states, in order, are also the largest exporters by truck to Mexico. 
Imports from Mexico to U.S. States:

Texas is by far the largest importer from Mexico, followed by California and Michigan. Fifty percent of the value of the merchandise imported to Texas is electrical machinery, and nuclear reactors \& boilers. The same holds true for California. Rail has a small share of the import movement to Texas and California. Rail moves twothirds of the imports from Mexico to Michigan, these being primarily vehicle parts. Rail also has a significant share of 15 percent or more of import value movement to Arizona, Illinois, Georgia, and Tennessee. As far as total dollar value is concerned, Michigan, Texas, and Arizona are the leaders for rail imports. Texas, California, and Michigan, in that order, have the highest dollar value of surface freight imports. This order is also true for truck import movement.

\subsection{Discussion}

Considering rail alternatives to relieve the strain on an overburdened trucking system that is attempting to move the great majority of surface exports and imports among the NAFTA countries, requires analysis of several issues. One is adaptability of a commodity for movement by rail across borders. Of the top 25 commodities in each export and import category to and from Canada, only a few are not adaptable to rail movement. These include pharmaceutical products, edible vegetables, fish and crustaceans, and live animals. These commodities are perishable and time-sensitive; a characteristic rails are not known for. All of the other commodities listed could easily move by rail without any handling problems.

Few commodities moving between the U.S. and Mexico are not suitable for rail movement. Of the top 25 export commodities to Mexico, only meat and edible meat appear to be unfriendly to rail movement. Edible vegetables and fish/ crustaceans are the only two of the top 25 import commodities from Mexico not adaptive to rail movement. Otherwise, just as in the case of Canadian trade, the great majority could easily move by rail.

A second factor determining appropriateness of a commodity for rail transborder movement is the distance the commodity is to move. No doubt, shorter distances favor truck movement because of the lower fixed cost trucking structure. As the distance increases, rails' cost advantage of lower variable cost comes into play enabling the rails to charge lower rates than truck.

Commodity flow movements among the NAFTA participants include short distances and longer journeys. Because of the high fixed-cost structure of rail, movements of less than 400 miles are generally considered to the too short to make rail cost effective. Movements from 500-to 750-miles are considered medium haul and rail competitive. The rail cost and rate advantage is heavily favored for movements over 750 miles.

Of the top 25 export movement combinations between the U.S. and Canada, the top four were shorter trip moves between Michigan, Ohio, Illinois, New York, and Ontario. Longer commodity flows in the top 25 that would be conducive to rail movement are those such as: Texas to Ontario, California to Ontario, North Carolina to Ontario, Tennessee to Ontario, Georgia to Ontario, Kentucky to Ontario, and Missouri to Ontario. At least 14 of the top 25 combinations are sufficient to make rail a cost effective alternative to truck. Surface imports from Canada to the U.S. also reflect many combination flows that are long enough in distance to warrant rail movement. Although not as many as the export combinations, at least 9 of the top 25 province-state movements are cost effective moves by rail.

Surface transportation flows between the U.S. and Mexico show considerable opportunity for increased rail utilization. At least 8 of the top 25 export flows to Mexico are of sufficient distance to make rail a viable alternative. Twenty-two of the top 25 Mexican import flow combinations are of sufficient distances to make rail rates more cost effective than truck.

Finally, even though railroads are the low cost leader, in terms of freight rates, for longer surface transborder commodity movements, their transit times are extremely poor when compared to truck. In many cases, rail transit time is five times as long as truck. This transit time deficit puts the rails at a significant disadvantage for 
commodities that have any degree of time-sensitivity.

\subsection{Environmental Impact of More Nafta Trucks}

The prospect of an ever increasing number of trucks to move the NAFTA commodities has many serious consequences including social, economic, and infrastructure costs. None the least of these consequences are the environmental impacts. The U.S. Environmental Protection Agency estimates that for every ton-mile, a typical truck emits roughly three times more nitrogen oxides and particulates than a rail locomotive. Other studies suggest that trucks emit six to twelve times more pollutants per ton-mile than do railroads, depending upon the pollutant measured. According to the American Society of Mechanical Engineers, 2.5 million fewer tons of carbon dioxide would be emitted into the air annually if only 10 percent of U.S. intercity freight now moving by highway were shifted to rail (AAR statfact, 2001).

Given that the U.S. is facing an upward spiral in fuel prices, fuel efficiency is becoming more important with each passing day. Railroad fuel efficiency increased 63 percent from 1980 to 1998 . In 1980 a gallon of diesel fuel moved a ton of rail freight an average of 235 miles. In 1998, a ton of freight by rail moved an average of 384 miles per gallon. On average, railroads are three times more fuel efficient than trucks (AAR statfact, 2001). Clearly, rails favor the environment over trucks.

\subsection{Conclusions}

Many factors impact the potential for extensive use of rail for international movement of goods among Canada, the U.S. and Mexico. The major considerations are the adaptability of the commodities for rail movement, the volume of commodity available for movement, rail transit time, on-time delivery, reliability, availability of service, and rates. The study found a significant number of the top commodities with adequate volume and adaptability for rail movement.

The prime weaknesses of a rail alternative are found in service frequency, timeliness and service provision. Rail movements on north-south routes are not nearly as structured or geared toward time sensitivity as the east-west rail movements across the U.S. which are very time competitive, if not better than truck movement. Rail generally takes at least twice as long as truck from Canada to many of the U.S. and Mexican destinations no matter which rail route is used. This transit disparity is also true for the south-north moves.

Efficient and adequate rail operations for international commodity movement would benefit all, from shippers and carriers to regional economies, as well as the environment. Rail movement of NAFTA commodities has enormous growth potential, but it must operate on time, more frequently, and more quickly. On-time and faster service will not only require infrastructure, tracking structure, speed and signaling, but also operating discipline and service capability. Complex planning and scheduling problems must be addressed and solved by all participants that would be impacted by this intermodal process. With the wave of recent rail mergers, namely BN-SF (1995), UP-SP (1996), CP-IC (1999), CSX-Conrail (1999), and NS-Conrail (1999), expanding single-line service should create new opportunities for such movement alleviating some of the present problems associated with rail service. Hopefully, one of the positive outcomes of the mergers will be manifest by long-run service improvements in rail capabilities to move NAFTA commodities.

\section{References}

1. ATA Intermodal Trucking Services Guide, 1997 ed.

2. “Annual Report on Exports," Western Centre for Economic Research,” Edmonton, 1996.

3. Bureau of Transportation Statistics, Transborder Surface Freight Data, 2002. www.bts.gov/transborder/

4. Bureau of Transportation Statistics (1999a), 1997 Commodity Flow Survey, (Washington, DC: US Dept. of Transportation and US Dept. of Commerce)

5. "CANAMEX Trade Corridor- A Unique Transportation Partnership," Alberta Transportation and Utilities, Edmonton, 1997. 
6. Leonard's Guide - National Third Party Logistics Directory, 1997 ed.

7. "Mexican Truck Crossings Are Disputed," Transport Topics, April 23, 2001. p. 34

8. "Railroads: Building A Cleaner Environment," Association of American Railroads, 2001, www.aar.org/comm/statfact.n

9. The Official Intermodal Guide, 1999 ed.

10. Wall Street Journal, October 21, 1996, p.1.

Notes 
Notes 